\title{
A Review on Corona Virus (Sars-Cov-2)
}

\author{
Aman Mittal $^{1 *}$, Tanushi Chauhan ${ }^{2}$, Kanupriya Chauhan ${ }^{3}$
}

${ }_{1}^{1}$ Associate Professor, Global Institute of Pharmaceutical Education and Research, Kashipur Uttarakhand India
${ }^{2} \mathrm{PG}$ student, Global Institute of Pharmaceutical Education and Research, Kashipur Uttarakhand India
${ }^{3}$ Lecturer, Global Institute of Pharmaceutical Education and Research, Kashipur Uttarakhand India

DOI: $10.36347 /$ sajp.2020.v09i12.001

| Received: 19.11.2020 | Accepted: 01.12.2020 | Published: 07.12.2020

*Corresponding author: Aman Mittal

\section{Abstract}

Recently positive sense - nCoV have originated from Hubei, especially in Wuhan, China has been reported as pathogenic, which cause severe respiratory tract infection. The name is derived from the outer fringe, formed from spike protein. It might be responsible for causing significant human mortality. Unfortunately, to date, there is no effective treatment available against this virus. There is an urgent need to develop new strategies to prevent or control corona virus infections. The goal of this review is to provide (as we were possible) all the genomic, lifecycle, incubation, symptoms, diagnosis, and suggestive treatment information, of SARS-CoV-2, which help in developing pioneer therapeutic agent.

Keywords: SARS-CoV-2, $\beta$-corona virus, nCoV, RNA, respiratory infection, genomic, incubation, pathogenic, MARS-CoV, COVID-19 etc.

Copyright (C) 2020 The Author(s): This is an open-access article distributed under the terms of the Creative Commons Attribution 4.0 International License (CC BY-NC 4.0) which permits unrestricted use, distribution, and reproduction in any medium for non-commercial use provided the original author and source are credited.

\section{INTRODUCTION}

At the end of 2019, an RNA virus, designated as 2019-nCoV, emerged in Wuhan, Hubei, China, sparking global public health institutions after SARS$\mathrm{CoV}$ (severe acute respiratory syndrome corona virus) in 2002 and MARS-CoV (Middle East respiratory syndrome corona virus) in the 2012 outbreak. On Feb. $11^{\text {th }}, 2020$, the "2019-nCoV" was officially renamed as "SARS-CoV-2". The disease caused by this virus was called "corona virus disease 2019" or COVID-19. On Dec. $7^{\text {th }}, 2019$ virus firstly occurred and detected, china quickly inform this to W.H.O. and share data of this out breaking virus. W.H.O. takes a rapid action on this causative virus, issues guidelines for diagnosis, precaution, and measurement is taken for nCoV. On 11 March 2020, the disease should be characterized as a pandemic. Many countries, along with America and India many countries start screening of travelers from China, intended to detect the virus before spreading.

\section{Type}

Corona virus's classification has been based on genomic organization, similarities in the genomic sequence, antigenic properties of viral proteins, replication strategies, and structural characteristics of virions, pathogenic, cytopathogenic, and physicochemical properties Coronavirus belongs to the subfamily coronavirinae of family Coronaviridae in
Nidovirales order. Corona virinae subfamily should be classified into several genera:

- $\alpha$-coronavirus

- $\quad \beta$-coronavirus, further divided into SARS-CoV and MARS-CoV

- $\gamma$-coronavirus

- $\delta$-coronavirus

\section{Genomic structure}

Corona virions are spherical (dia. of approx $125 \mathrm{~nm})$. The genome of $\mathrm{CoV}$ should be composed of 5 structural proteins: spike (S), membrane (M), envelop (E), Hemagglutinin Esterase (HE), and Nucleocapsid (N) (Table 1).

Life cycle

- Involve several steps:

a) Attachment and entry

b) Replicase protein expression

c) Replication and transcription

d) Assembly and release

- $\mathrm{CoV}$ is attached to a specific surface receptor through $\mathrm{S}$ protein; conformational changes allow the entry of viruses inside the cell.

- Single-stranded, non-segmented viral RNA (approx. 26-32kb) release in the host cytoplasm

- 7 genes contributed to the viral genome: 
- Replicase genes (gene 1 ) carry $2 / 3$ part of the nonstructural protein region at 5 ' end.

- Genes 2-7 present on structural and accessory protein region at 3 ' end.

- Replicase genes encode 2 reading frame shifts, ORF1a and ORF1b, which undergoes translation to form ppla (496kDa) and pp1b (802kDa) respectively.

- Autolytic processing of pp1a and pp1b, form nsp (non-structural protein) composed of 16 units (nsp1-nsp16).

- In RTC (Replicase transcriptase complex), the collection of nsp proceeds subgenomic RNAs replication and transcription.

- After transcription S, E, and M protein of positive sense gRNA, inserted in the endoplasmic reticulum (ER) of the host cell, while $\mathrm{N}$ protein and some $\mathrm{M}$ protein form nucleocapsid, inserted in ERGIC.

- Inside ERGIC, N proteins encapsulate viral RNA and boost virions maturation.

- Mature virions are packed in smooth-walled vesicles and transported to the host cell wall. Some $S$ proteins move to the host cell surface and facilitate cell to cell interaction between virions and host cell by forming giant, multinucleated bud, which are undetected by host antibodies and spread in the host body.

\section{Incubation}

The incubation period of $\mathrm{nCoV}$ on an average is up to 14 days. At this stage, the infected patient has the potential to infect an averagely 3.77 other healthy peoples. Due to the ability to mutate rapidly, SARSCoV-2 is highly contagious. According to the report of W.H.O, hospitalized cases can reach up to 25 lakh people in the High scenario, 17-18 lakh people in the Medium scenario, and 13 lakh people in the Low scenario (Table 2).

\section{Transmission}

Ro (basic reproduction rate) calculates the contagiousness of the virus. It represents the number of cases, then a case of the disease generate throughout its infectious period in a susceptible population. If Ro $>1$, the number of infected patients increases with stronger transmission potential. If Ro $<1$, transmission should be diminished eventually. WHO estimates Ro from1.4 to 2.5whereas, Ying Liu et.al estimated the Ro value of COVID-19 was 3.28, which exceeds the WHO estimation.

\section{The Transmission should be processed}

- During coughing and sneezing, respiratory fluid droplets of an infected patient should be dispersed into the air that may be inhaled by normal people.
- Shaking hands or touching the surface where might be the virus present and then-after touching the eyes, nose, or mouth also has a significant contribution in preceding the chain of transmission.

\section{Source of infection}

Bats, pangolins, and snakes should be considered as the primary and natural hosts for the virus. A study conducted by Penking University shows the probability of causing infection via snakes, but a later study does not show any such type of shreds of evidence. $\mathrm{Xu}$ et al. shows $99 \%$ similarity in virus found in pangolins and currently infected patients, using electron microscopic and molecular biological analysis, while the Wuhan institute of virology study conducted on $\mathrm{nCoV}$ and bats shows $96.2 \%$ similarity. However, until the date, no study fully elucidates the potential natural and intermediate host of the virus.

\section{Symptoms}

Due to mutation the virus produces no symptoms or symptoms that vary from person to person include:

\section{Mild Illness}

Sore throat, mild fever, nasal congestion, malaise, headache, muscle pain, dry cough, fatigue.

\section{Moderate Pneumonia}

Coughs, breathlessness (tachypnea in children) are present without signs of severe pneumonia.

\section{Severe Pneumonia}

Fever is associated with severe dyspnea, respiratory distress, tachypnea (> 30 breaths/min), and hypoxia ( $\mathrm{SpO} 2<90 \%$ on room air).

\section{Acute Respiratory Distress Syndrome (ARDS)}

This syndrome is suggestive of a serious newonset respiratory failure or for worsening of an already identified respiratory infection.

- Mild ARDS: $200 \mathrm{mmHg}<\mathrm{PaO} 2 / \mathrm{FiO} 2 \leq 300$ $\mathrm{mmHg}$.

- Moderate ARDS: $100 \mathrm{mmHg}<\mathrm{PaO} 2 / \mathrm{FiO} 2 \leq 200$ $\mathrm{mmHg}$.

- $\quad$ Severe ARDS: $\mathrm{PaO} 2 / \mathrm{FiO} 2 \leq 100 \mathrm{mmHg}$.

\section{Sepsis}

Sepsis represents a life-threatening organ dysfunction caused by a dysregulated host response to suspected or proven infection, with organ dysfunction. It includes respiratory manifestations such as severe dyspnea and hypoxemia, renal impairment with reduced urine output, functional alterations of organs, tachycardia, and altered mental status. 


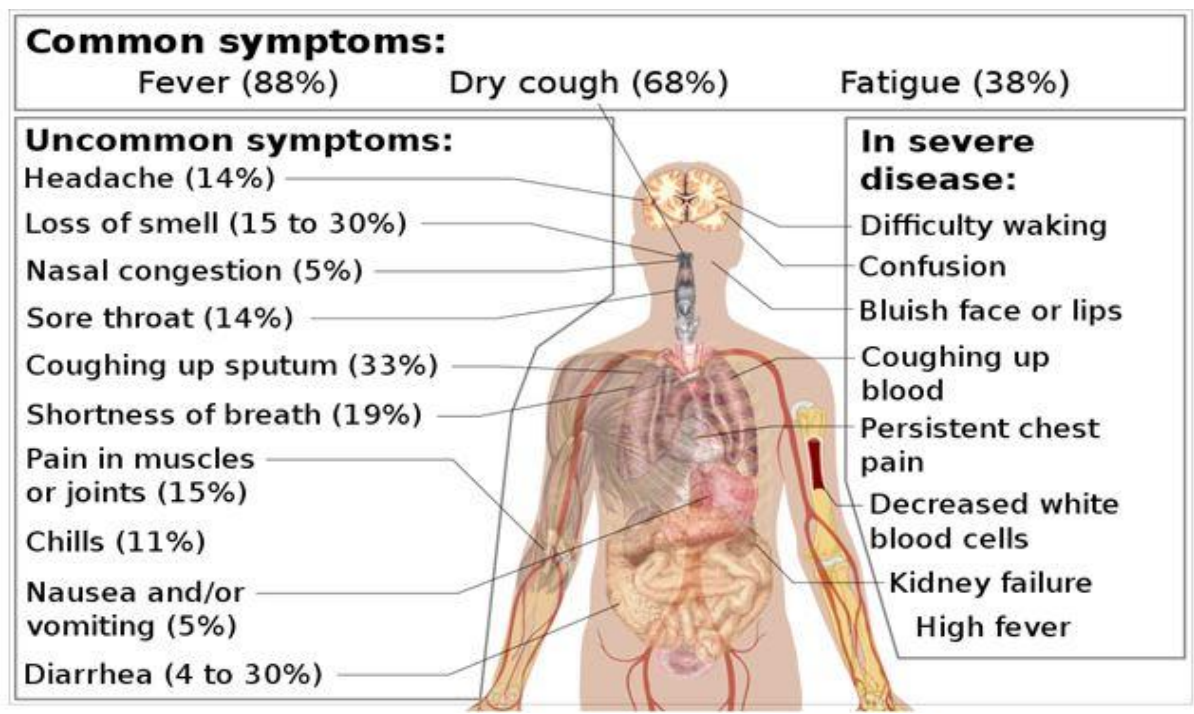

Symptoms to Corona Virus Diseases

\section{Diagnosis and Treatment}

The virus can be diagnosed by various techniques such as Computer tomography(CT)imaging, Serological tests or Western blots, real-time fluorescence (RT-PCR), rRT-PCR, RT-LAMP, rRTLAMP, corona virus kit.

To date, no specific treatment has been found. Oxygen therapy (ventilator) plays a lead role in the treatment. Several drugs based on their efficacy are used as a choice of treatment, Table no. 3 (all these should be symptomatic).

\section{Mesenchymal stem cells (MSCs)}

MSC is the non- hematopoietic adult stem cell, isolated from different tissues and are involved in the immunoregulatory activities by secreting paracrine factors. A study performed by Chen and co-workers shows the improved survival rateofH7N9 induced ARDS by the use of MSC. They also provide a philosophical background for treatingH7N9 induced ARDS through preclinical and clinical research.

Another study conducted in China with US cooperation, recruited 7 Ccovid-19 pneumonia patients from Jan. 23 to Feb. 16. MSC transplantation should be carried out in all patients and demonstrated the clinical signs consecutively for 14 days. The study discloses the improvements in clinical symptoms and the marked decrease in pro-inflammatory cytokines, numbers of hyper-active cytokines secreting immune cells. Additionally, CRP concentration was diminished, while the number of peripheral lymphocytes and IL-10 levels raises dafter transplantation. Because, H7N9 and COVID19 show similar clinical complications, MSC based treatment should be a feasible treatment option for $\mathrm{nCoV}$ disease.

\section{Convalescent plasma (CP)}

$\mathrm{CP}$ is a strong plasma Antibody treatment that helps those COVID-19 patients whose body is unable to produce enough antibodies to fight $\mathrm{nCoV}$ disease. In this therapy, Dr. isolates the antibodies from the blood of the recovered patient and administered these antibodies to the currently infected patient. These antibodies detect, neutralize, and phagocytosed the pathogen. The effectiveness of CP is studied by Duan et al. on COVID-19 patients and evaluate that within 3 days, the concentration of reactive protein was deceased, with increased antibodies and oxyhemoglobin saturation level without any adverse effect. A descriptive study conducted by China in various laboratories and clinics found improvement in COVID19 patients after receiving $\mathrm{CP}$.

Still, there is an urgent need for multicenter clinical trials to conclude the $\mathrm{CP}$ dosage regimen.

\section{Prevention}

Preventive strategies are focused on the isolation of patients and careful infection control. The WHO and other organizations have issued the following recommendations:

- Don't shake the hand

- Wash hand or use sanitizer after touching any public surfaces where might be the virus present.

- Don't touch eyes, nose, or mouth frequently.

- Always cover face by mask, handkerchief during coughing/sneezing, etc.

- Never going to crowded places.

- Maintain proper physical distancing

- Avoid unprotected contact with farm or wild animals.

- In case of symptoms, seek medical care early

- To follow the advice given by your healthcare provider

Confirmed or suspected cases with mild illness should be recommended to stay separately at home. The ventilation at home should be good enough to provide an adequate amount of sunlight for virus destruction. 
Patients should wear a simple surgical mask, practice cough, and hand hygiene in every 15-20 $\mathrm{min}$.
Prevention is the best method to break the virus chain of transmission.

Table-1: Role of each viral protein

\begin{tabular}{|l|l|}
\hline S protein & $\begin{array}{l}\text { The outermost layer, give structural and form homotrimers, allow crown-like morphological } \\
\text { changes, due to which the virus is termed as coronavirus. Play a role in the binding of virions to } \\
\text { specific surface receptors of the host cell }\end{array}$ \\
\hline E protein & Approx.76-109 amino acids protein helps in virions assembling and morphogenesis in a cell. \\
\hline M protein & Regenerate virions in ERGIC complex inside the cell \\
\hline N protein & $\begin{array}{l}\text { The innermost Phosphoproteins layer, provide a flexible structure to viral RNA by binding to the } \\
\text { helix and allow replication and transcription. }\end{array}$ \\
\hline HE protein & Present on virions surface \\
\hline
\end{tabular}

ERGIC- Endoplasmic reticulum-Golgi apparatus intermediate compartment.

S-spike

M- Membrane

E- Envelop

HE- Hemagglutinin Esterase

$\mathrm{N}$ - Nucleocapsid

Table-2

\begin{tabular}{|l|l|l|}
\hline State & Death & Positive Cases \\
\hline Andaman and Nicobar Islands & 0 & 33 \\
\hline Arunachal Pradesh & 0 & 27 \\
\hline Assam & 4 & 1390 \\
\hline Bihar & 23 & 3945 \\
\hline Chandigarh & 4 & 301 \\
\hline Chhattisgarh & 1 & 498 \\
\hline Dadra and Nagar Haveli & 0 & 3 \\
\hline Daman and Diu & 0 & 0 \\
\hline Goa & 0 & 79 \\
\hline Gujarat & 1092 & 17,632 \\
\hline Haryana & 21 & 2356 \\
\hline Himachal Pradesh & 6 & 345 \\
\hline Jharkhand & 5 & 712 \\
\hline Karnataka & 52 & 3408 \\
\hline Kerala & 11 & 1412 \\
\hline Lakshadweep & 0 & 0 \\
\hline Madhya Pradesh & 358 & 8283 \\
\hline Maharashtra & 2468 & 72,300 \\
\hline Manipur & 0 & 89 \\
\hline Meghalaya & 1 & 27 \\
\hline Mizoram & 0 & 1 \\
\hline Nagaland & 0 & 43 \\
\hline Delhi & 556 & 22,132 \\
\hline Pondicherry & 1 & 80 \\
\hline
\end{tabular}

State/UT wise list of COVID confirmed cases in India, on June 2. 
Table-3: Suggestive COVID treatments

\begin{tabular}{|c|c|c|c|c|}
\hline Drug & Mechanism & Targeted disease & Mode of Action & Status \\
\hline Eidd-2801 & RNA polymerase inhibitor. & $\begin{array}{l}\text { influenza, Ebola, } \\
\text { coronaviruses, and } \\
\text { VEEV }\end{array}$ & $\begin{array}{l}\beta-\mathrm{D}-\mathrm{N} 4- \\
\text { hydroxycytidine is a } \\
\text { ribonucleoside } \\
\text { analog }\end{array}$ & Investigational \\
\hline Oseltamivir & $\begin{array}{l}\text { Inhibiting the activity of the viral } \\
\text { neuraminidase enzyme, preventing } \\
\text { budding from the host cell, viral } \\
\text { replication, and infectivity. }\end{array}$ & Influenza virus $\mathrm{A}$ & $\begin{array}{l}\text { Neuraminidase } \\
\text { inhibitor }\end{array}$ & Approved \\
\hline Ribavirin & $\begin{array}{l}\text { Interfering with the synthesis of viral } \\
\text { mRNA. }\end{array}$ & $\begin{array}{l}\text { HCV, SARS, } \\
\text { MERS }\end{array}$ & $\begin{array}{l}\text { Synthetic guanosine } \\
\text { nucleoside }\end{array}$ & Approved \\
\hline $\begin{array}{l}\text { Lopinavir/ } \\
\text { Ritonavir } \\
(400 / 100 \mathrm{mg} \\
\text { every } 12 \mathrm{~h}) \\
\end{array}$ & $\begin{array}{l}\text { Inhibiting HIV-1 protease for protein } \\
\text { cleavage, resulting in non-infectious, } \\
\text { immature viral particles. }\end{array}$ & $\begin{array}{l}\text { HIV/AIDS, } \\
\text { SARS, MERS }\end{array}$ & Protease inhibitors & Approved \\
\hline $\begin{array}{l}\text { Remdesevir } \\
\text { (GS-5734) }\end{array}$ & Interfering with virus post-entry. & $\begin{array}{l}\text { Ebola, SARS, } \\
\text { MERS }\end{array}$ & $\begin{array}{l}\text { Nucleotide analog } \\
\text { prodrug }\end{array}$ & Experimental \\
\hline $\begin{array}{l}\text { chloroquine } \\
\text { (CQ) }(500 \mathrm{mg} \\
\text { every } 12 \mathrm{~h})\end{array}$ & $\begin{array}{l}\text { Increasing endosomal } \mathrm{pH} \text {, } \\
\text { immunomodulating, autophagy inhibitors. }\end{array}$ & $\begin{array}{l}\text { Malaria, } \\
\text { Autoimmune } \\
\text { disease }\end{array}$ & 9-aminoquinolin & $\begin{array}{l}\text { Approved, } \\
\text { Investigational, vet } \\
\text { Approved }\end{array}$ \\
\hline Nitazoxanide & $\begin{array}{l}\text { Modulating the survival, growth, and } \\
\text { proliferation of a range of extracellular } \\
\text { and intracellular protozoa, helminths, } \\
\text { anaerobic and microaerophilic bacteria, } \\
\text { viruses. }\end{array}$ & $\begin{array}{l}\text { A wide range of } \\
\text { viruses }\end{array}$ & Antiprotozoal agent & $\begin{array}{l}\text { Approved, } \\
\text { Investigational, vet } \\
\text { Approved }\end{array}$ \\
\hline Nafamostat & $\begin{array}{l}\text { Prevents membrane fusion by reducing } \\
\text { the release of cathepsin B; anticoagulant } \\
\text { activities }\end{array}$ & $\begin{array}{l}\text { Influenza, MERS, } \\
\text { Ebola }\end{array}$ & $\begin{array}{l}\text { Synthetic serine } \\
\text { protease inhibitor }\end{array}$ & Investigational \\
\hline $\begin{array}{l}\text { Remdesivir (GS- } \\
\text { 5734) }\end{array}$ & Interfering with virus post-entry & $\begin{array}{l}\text { Ebola, SARS, } \\
\text { MERS }\end{array}$ & $\begin{array}{l}\text { Nucleotide analog } \\
\text { prodrug }\end{array}$ & Experimental \\
\hline $\begin{array}{l}\text { Penciclovir/ } \\
\text { Acyclovir }\end{array}$ & $\begin{array}{l}\text { A synthetic acyclic guanine derivative, } \\
\text { resulting in chain termination }\end{array}$ & HSV, VZV & Nucleoside analog & Approved \\
\hline
\end{tabular}

HIV- Human immunodeficiency virus

AIDS- Acquired immune deficiency syndrome

HCV-Hepatitis $\mathrm{C}$ virus

HSV -Herpes simplex virus

VZV -Varicella-zoster virus

\section{CONCLUSION}

Currently, the corona virus research will be continuing. These viruses continue to emerge and to evolve and cause human and veterinary outbreaks owing to their ability to recombine, mutate, and infect multiple species and cell types. Many of the nonstructural and accessory proteins encoded by these viruses remain uncharacterized with no known function, and it will be important to identify mechanisms of action for these proteins as well as defining their role in viral replication and pathogenesis. Once this pandemic ends, one will be able to assess the health, social, and economic impact of this global disaster and we should be able to learn a lesson from this disease for a future pandemic. Finally, the knowledge of how the corona virus can cause disease and host immuno pathological responses, help in the development of safe and effective therapeutic agent against this deadly virus.

\section{REFERENCES}

1. Rabby Md Insiat Islam, Current Drugs with Potential for Treatment of COVID-19: A Literature Review, J Pharm. Pharm. Sci, 2020, 23: 58-64.
2. Sahin AR, Erdogan A, Agaoglu PM, Dineri Y, Cakirci AY, Senel ME, Okyay RA, Tasdogan AM. 2019 novel coronavirus (COVID-19) outbreak: a review of the current literature. EJMO. 2020;4(1):1-7.

3. Tidwong N, Montakantikul P, Manosuthi W. Pharmacological treatment for the Novel Coronavirus disease 2019 (COVID-19 Infection). Pharmaceutical Sciences Asia Review. 2020;47(2):97-103.

4. Unhale SS, Ansar QB, Sanap S, Thakhre S, Wadatkar S, Bairagi R, Sagrule S, Biyani KR. World Journal of Pharmaceutical and Life Sciences.

5. Erin K. McCreary, and Jason M. Pogue, COVID19 Treatment: A Review of Early and Emerging Options, OFID, 2020.

6. Lu R, Zhao X, Li J, Niu P, Yang B, Wu H, Wang W, Song H, Huang B, Zhu N, Bi Y. Genomic characterisation and epidemiology of 2019 novel coronavirus: implications for virus origins and receptor binding. The Lancet. 2020 Feb 22;395(10224):565-74. 
Aman Mittal et al., Sch Acad J Pharm, Dec, 2020; 9(12): 330-335

7. Van Der Hoek L, Pyrc K, Jebbink MF, VermeulenOost W, Berkhout RJ, Wolthers KC, Wertheim-van Dillen PM, Kaandorp J, Spaargaren J, Berkhout B. Identification of a new human coronavirus. Nature medicine. 2004 Apr;10(4):368-73.

8. Di Gennaro F, Pizzol D, Marotta C, Antunes M, Racalbuto V, Veronese N, Smith L. Coronavirus diseases (COVID-19) current status and future perspectives: a narrative review. International journal of environmental research and public health. 2020 Jan;17(8):2690.

9. Fehr AR, Perlman S. Coronaviruses: an overview of their replication and pathogenesis. InCoronaviruses 2015 (pp. 1-23). Humana Press, New York, NY.

10. Tok TT, Tatar G. Structures and functions of coronavirus proteins: Molecular modeling of viral nucleoprotein. Int $\mathbf{J}$ Virol Infect Dis. 2017;2(1):001-7.

11. Xu J, Zhao S, Teng T, Abdalla AE, Zhu W, Xie L, Wang Y, Guo X. Systematic comparison of two animal-to-human transmitted human coronaviruses: SARS-CoV-2 and SARS-CoV. Viruses. 2020 Feb;12(2):244.

12. Cascella M, Rajnik M, Cuomo A, Dulebohn SC, Di Napoli R. Features, evaluation and treatment coronavirus (COVID-19). InStatpearls [internet] 2020 Mar 8. StatPearls Publishing.

13. Ahmad T. Scenario of the Corona Virus (COVID19) in India. Available at SSRN 3568847. 2020 Apr 5.

14. Woo PC, Huang Y, Lau SK, Yuen KY. Coronavirus genomics and bioinformatics analysis. Viruses. 2010; 2: 1804-20.

15. Lisheng Wang, Yiru Wang, Dawei Ye, Qingquan Liu, Review of the 2019 novel coronavirus (SARS$\mathrm{CoV}-2$ ) based on current evidence, International Journal of Antimicrobial Agents. 2020,55: 1-7.

16. Singhal Tanu. A Review of Coronavirus Disease2019 (COVID-19), The Indian Journal of Pediatrics, April 2020, 87(4):281-286.

17. NaserGhandi A, Allameh SF, Saffarpour R. All about COVID-19 in brief. New Microbes and New Infections. 2020 May;35.

18. Valencia Damian N., Brief Review on COVID -19: The 2020 pandemic caused by SARS-CoV2, Cureus. 2020, 12(3), 1-13.

19. Asai A, Konno M, Ozaki M, Otsuka C, Vecchione A, Arai T, Kitagawa T, Ofusa K, Yabumoto M, Hirotsu T, Taniguchi M. COVID-19 drug discovery using intensive approaches. International journal of molecular sciences. 2020 Jan;21(8):2839.

20. Kachroo V. Novel coronavirus (COVID-19) in India: Current scenario. International Journal of Research and Review. 2020;7(3):435-47.

21. Nuttall I, Dye C. The SARS wake-up call. Science. 2013; 339: 1287-1288.

22. Kannan Subbaram, Shaik SyedAli Pakeer, Sheeza A, Hemalatha K, COVID-19 (Novel Corona Virus 2019)- Recent Trend, European Review for Medical and Pharmacological Sciences. 2020; 24: 2006-2011.

23. Guo yan-Rang, Yan Yan, Cao Qing-Dong, Tan Yuan-Yang, Chen Shou-Deng, Jin Hong-Jun. The Origin, Transmission and Clinical Therapies on corona Virus Disease 2019(COVID-19) Outbreak an Update on the Status, Military Medical Research; 2020, 7:11, 1-10.

24. Hsu LY, Chia PY, Lim, JF. The Novel coronavirus (SARS-CoV-2) epidemic. Ann. Acad. Med. Singap. 2020, 49, 1-3.

25. Mehra Kumar Nilesh, Thakur Pradip, Singh Shashi Bala, Bhavana Valamla, COVID-19: pathophysiology, treatment option, nanotechnology approaches, and research agenda to combating the SARS-CoV2 pandemic, Life Sciences. 2020, 261: $1-17$.

26. Cui J, Li, F, Shi ZL. Origin and evolution of pathogenic coronaviruses. Nat. Rev. Microbiol. 2019, 17, 181-192.

27. Goodarzi Pedram, Mahdavi Farzad, Zamanif Farhad, Sohrabif Masodreza, Alireza Tabibzadehg, Jedag Ali Salimi, Keyvanif Hossein, Coronavirus disease 2019(COVID-19): Immunological approaches and emerging pharmacological treatments, International Immunopharmacology. 2020, 88:1-13.

28. Silva Jaime A. Teixeira da, Convalescent plasma: A possible treatment of COVID-19 in India, Medical journal Armed Forces India. 2020, 76: 236-237.

29. Sethna PB, Hofmann MA, Brian DA. Minus-strand copies of replicating coronavirus mRNAs contain antileaders. Journal of virology. 1991; 65(1):320 325.

30. Keck JG, Makino S, Soe LH, Fleming JO, Stohlman SA, Lai MM. RNA recombination of coronavirus. Advances in experimental medicine and biology. 1987; 218:99-107. 